\title{
Henri Dunant, Founder Of The International Red Cross
}

\author{
JSG Blair
}

10th December 2001, was the hundredth anniversary of the presentation of the first Nobel Peace Prize to Mr Henri Dunant for the foundation of the International Red Cross Organisation. While his long life had great success, it also saw a great deal of illtreatment and suffering.

Jean-Henri Dunant was born on 8th May 1828 into a well to do and aristocratic Calvinist Protestant family of Geneva. His mother, especially, influenced him from a young age to respect Christian love and to care for his fellows. His parents both showed their belief in active help to the poor, orphans, and those in the harsh prisons of the time. His childhood was happy and quiet. When he was 25 years of age, he served as an exchange clerk in a bank in Geneva. Early in his life he was concerned with the practice of slavery. In his work he visited Algeria to help with its financial development and was in contact with Napoleon III himself in this aim.

In June of 1859, Dunant was in Italy and his visit to the Emperor coincided with Napoleon's military moves against Austria. Being almost, therefore, by chance beside Solferino on 24th June that year, Dunant experienced his sight of that battle and as a result was, as he said later, 'seized with an almost religious belief' that he must do something for the suffering of wounded in war. His 'Souvenir de Solferino' showed his great dramatic narrative ability and sense of history. Perhaps his reading of the actions of Florence Nightingale in the Crimea had also affected his feelings.

By 1859, infantry bullets, now oblong and conical instead of spherical as previously, had become more precise and deadly. The artillery too, with rifled gun barrels, more powerful charges, and ever increasing power of projectiles, produced much more serious

Dr JSG Blair OBE KStJ TD TAVRD BA ChM DLitt (honoris causa) FRCS FRCP FICS DRCOG FRHistS FSA (Scot)

World Vice President, International Society for the History of Medicine

The Brae,

143 Glasgow Road, Perth

PH2 0LX

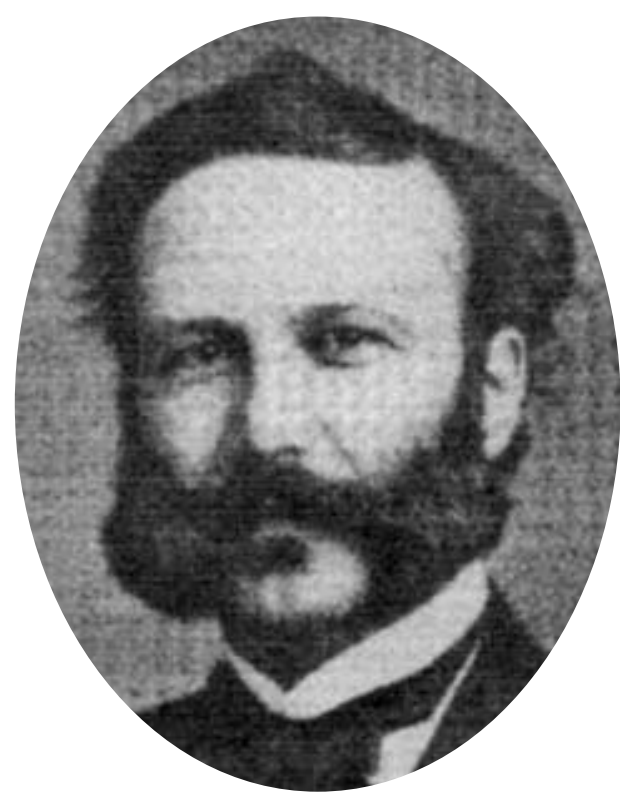

Fean-Henri Dunant

above all, on the outskirts of the town of Solferino. The crops were destroyed, the harvests down-trodden, the hedges ripped out and the orchards laid waste. From time to time one came upon blood baths; the towns and villages were deserted and bore all the signs of musketry, bombs, grenades, howitzers.' He gave as much assistance as he could. Dunant, a citizen of Geneva, there and then, dedicated the rest of his life to the task of organising and assisting those injured in battle; he who is injured cannot be considered an enemy because, given his or her defenceless state, he can only be considered from a humane point of view, and hence, neutral. With reference to the soldier, pointless aggression and insult is added to injury:

"A San Martino, un officier de bersagliers, le captaine Pallavinci est blessè, ses soldiers le recoivant dans leus bras, ils le portent et le disposent dans une chapelle où iol recoit les premiers soins, mais les Autrichiens, momentamè nant repoussès, reviennent à la charge et pè nè trent dans cette èglise : les bersagliers, trop peu nombreaux de resister, son forcès d'abbondonner leur chef: des Croates, saissant de grosses perres qui se trouvent à la porte, en ècrasent la tête du pauvre capitaine cont la cervelle rejaolit sur leurs tuniques" (1).

Dunant's greatness lies in the fact that, once he had conceived his plan, he cleverly and diplomatically worked towards publishing his idea and having his proposal legally recognised. The wounded soldier is 
simply a person in need of assistance. If not helped, or a prisoner, he is destined to die or be liable to atrocious suffering. His walk of life which gave him access to those in high places because of his own social status, undoubtedly helped. After he published his Memoir of Solferino, he 'set to work to make sure that the mighty of the time got a copy. He sent it to the reigning houses of Europe and to many others. In his native Geneva, three humanitarian societies came to his aid - the Waldensian Society for Public Utility, the Geneva Society for Public Assistance, and lastly the Society for the Progress of Social Sciences of Neuchatel' (2).

In 1863, at the Geneva Society for Public Assistance, a 'commission of five' was set up. This was made up of four citizens of Geneva - Moynier, Appia, Mauniker and Dunant, and the general president, General Dufour. It quickly became an International Committee. The same year, Dunant went to the Berlin College of Statistics and used a session there to have his proposal read by a German friend. Many doctors present agreed at once to its contents. This was a big step forward. Next the Geneva Committee organised the first International Conference and it was during this, in August 1964, Dufour made a passionate speech urging the delegates to confirm the promises made in 1863 concerning neutrality of ambulances, the injured and medical personnel.
Delegates of twelve nations signed the Geneva Convention. Nations taking part now formed their national Red Cross Committee and these were involved in assistance to wounded persons. The legal backing was conformed by the International powers taking part.

Sadly, Dunant's absorption with his new project caused him to neglect his affairs so badly that he left them to an unscrupulous assistant. He was declared bankrupt in 1867. The Swiss bank concerned then accused him of misdemeanour, and he was discredited totally. For several years his isolation was hard to bear, but the award of the Nobel Prize again gave him funds to finance his charitable work and to repay those friends who had continued to support him. But his last years were sad ones, not an end deserved by a man who had done so much for wounded in war.

\section{References}

1. Henry Dunant, Un Souvenir de Solfèrino, CICR Publications, Gènève 1950. p21.

2. The First Nobel Peace Prize, (Henry Dunant, founder of the International Red Cross) and his 'Mèmoirs' Raimondo Ottiavani et al,Vesalius, Vol XI, No 1, June 2003.

Life of Jean-Henri Dunant - The Epic of the Red Cross or The Knight-Errant of Charity by Fernand Gigon, translated from the French by Gerald Griffin, London, Jarrolds Ltd, 1946. 